EXTENDED REPORT

\title{
Oestrogen receptor $\alpha$ gene polymorphisms in systemic lupus erythematosus
}

\author{
M Johansson, L Ärlestig, B Möller, T Smedby, S Rantapää-Dahlqvist
}

Ann Rheum Dis 2005;64:1611-1617. doi: 10.1136/ard.2004.032425

See end of article for authors' affiliations

Correspondence to: Dr Solbritt RantapääDahlqvist, Department of Rheumatology, University Hospital, SE-901 85 Umeå, Sweden; solbritt. rantapaa.dahlqvist@ medicin.umu.se

Accepted 3 April 2005 Published Online First 7 April 2005
Objective: To analyse associations of two oestrogen receptor $\alpha(O R \alpha)$ gene polymorphisms in 260 patients with SLE from northern Sweden. The two polymorphisms, Pvull T/C and the Xbal A/G, are located in the first intron of the OR $\alpha$ gene.

Methods: All patients fulfilling at least four of the ACR criteria for SLE were consecutively recruited during one year. The SLEDAI score and SLICC damage index were recorded. 670 individuals from the same geographical area served as controls. DNA from the patients and controls was extracted and genotyped using the 5' nuclease assay with an ABI PRISM 7900HT instrument. The genotype/phenotype relationships were calculated using SPSS.

Results: The unusual Pvull $C$ allele was associated with malar rash and the unusual Xbal $G$ allele with photosensitivity $(p=0.001, \mathrm{OR}=2.53,95 \% \mathrm{Cl}=1.43$ to 4.47 and $\mathrm{p}=0.007, \mathrm{OR}=2.12,95 \% \mathrm{Cl}=1.22$ to 3.66 , respectively). The common $\mathrm{Xbal} A \mathrm{~A}$ genotype was associated with serositis $(p=0.013, \mathrm{OR}=1.92$, $95 \% \mathrm{Cl}=1.15$ to 3.22). Based on the SLICC damage index associations of the common $\Pi$ genotype and AA genotype with cognitive impairment were identified $(p=0.018, O R=2.47,95 \% \mathrm{Cl}=1.17$ to 5.25 and $\mathrm{p}=0.018, \mathrm{OR}=2.75,95 \% \mathrm{Cl}=1.19$ to 6.38 respectively). There was also an association of the Xbal AA genotype with the angina/coronary artery bypass variable $(p=0.042, \mathrm{OR}=2.58,95 \% \mathrm{Cl}=1.03$ to 6.43$)$. Of the variables describing disease severity and duration it was found that carriers of the unusual Pvull $C$ allele showed a later onset of SLE $(p=0.02)$ and carriers of the unusual Xbal G allele a lower SLICC damage index.

Conclusions: The unusual Pvull $C$ and Xbal $G$ alleles were associated with a milder form of SLE characterised by skin manifestations, later onset, and less organ damage.
$\mathrm{S}$ ystemic lupus erythematosus (SLE) is an autoimmune disease of unknown aetiology predominantly affecting women. ${ }^{1-4}$ Both genetic and environmental factors are thought to contribute to disease susceptibility. Among the environmental factors are the female sex hormones, oestrogens, which have proinflammatory properties that might predispose to disease development. ${ }^{56}$ Oestrogen treatment is known to activate mature peripheral $\mathrm{B}$ cells in mice and may increase the production of IgG, including IgG antibodies against double stranded (ds) DNA, in peripheral blood mononuclear cells of SLE patients by enhancing B cell activity and by promoting interleukin 10 (IL10) production in monocytes. ${ }^{7}$ Higher levels of oestrogen and the oestrogen/ androgen ratio have been proposed to explain why women have a greater risk of developing SLE and why the flares appear at certain stages in life. The disease mostly affects women of childbearing age, ${ }^{10}$ and the risk of disease decreases in post-menopausal women in line with the decline of endogenous oestrogens. ${ }^{10}$ Administration of some oestrogen containing oral contraceptives ${ }^{11-13}$ and pregnancy $y^{14-18}$ may cause the disease to flare, and disease activity often fluctuates with the menstrual cycle. ${ }^{19}$

Oestrogens are mainly produced in the ovary and testis, but aromatisation of androgens also generates oestrogen in peripheral tissues and in adrenal glands. The effects of oestrogens are mediated through oestrogen receptors (ORs or ERs). There are two different kinds of oestrogen receptor, $\mathrm{OR} \alpha(6 \mathrm{q} 25.1)$ and $\mathrm{OR} \beta$ (14q22-24), which are homologous to each other. Both are ligand activated transcription factors and have the same structural characteristics and function as nuclear receptors. ${ }^{20}$

Oestrogen receptor $\alpha$ gene polymorphisms have been described as being associated with a various different complex diseases such as myocardial infarction, ${ }^{21}$ cognitive impairment, ${ }^{22}$ breast cancer, ${ }^{23}$ Alzheimer's disease, ${ }^{24}$ osteoporosis, ${ }^{25}$ rheumatoid arthritis, ${ }^{26}$ and lupus nephritis. ${ }^{27}$ In all of these reports the polymorphisms of the $\mathrm{OR} \alpha$ gene are designated PvuII and XbaI. However, the nomenclature has been inconsistent and quite confusing. Most results are derived using the restriction fragment length polymorphism (RFLP) method whereby PvuII and XbaI denote the restriction enzymes for two specific sites in intron 1 of the $\mathrm{OR} \alpha$ gene. PvuII $\mathrm{C}$ and $\mathrm{XbaI} \mathrm{G}$ equate to the absence of restriction site $(=\mathrm{Pl}=\mathrm{P}$ and $=\mathrm{Xl}=\mathrm{X}$, respectively $)$. Other names for PvuII T/C are: ESR1 c.454-397 T $\rightarrow$ C, IVS1-401 T/C, IVS1-397 T/C, ESRl nt $938 \mathrm{~T} \rightarrow \mathrm{C}$ (GeneBank: AF326912), and rs2234693. The XbaI A/G polymorphism has also been referred to as ESRl c.454-351 A $\rightarrow \mathrm{G}$, IVS1-354 A/G, IVSI$351 \mathrm{~A} / \mathrm{G}$, and rs9340799. ${ }^{21-29}$

Associations of the PvuII T/C and XbaI A/G polymorphisms have been reported in two studies on Asian patients with SLE. ${ }^{27}{ }^{30}$ The patients included in our cross sectional study were collected from the four most northern counties of Sweden. The population of northern Sweden is relatively homogeneous, making it well suited for genetic association studies. All individuals were diagnosed with SLE and their clinical phenotypes evaluated in relation to the polymorphisms of the OR $\alpha$ gene.

\footnotetext{
Abbreviations: ACR, American College of Rheumatology; SLE, systemic lupus erythematosus; SLEDAI, SLE activity index; SLICC, Systemic Lupus International Collaborating Clinics; SNP, single nucleotide polymorphism
} 
Table 1 Baseline characteristics of 220 female and 40 male patients diagnosed with systemic lupus erythematosus

\begin{tabular}{|c|c|c|c|}
\hline Variable & Total $(n=260)$ & Women $(n=220)$ & Men $(n=40)$ \\
\hline Age (years) (mean (SD)) & $51.4(15.2)$ & $51.2(14.4)$ & $52.5(18.9)$ \\
\hline Age of onset (years) (mean (SD)) & $39.0(15.7)$ & $38.4(15.0)$ & $42.4(19.1)$ \\
\hline \multicolumn{4}{|l|}{ ACR criteriał } \\
\hline 1. Malar rash & $149(57.5 \%)$ & $132(60.3 \%)^{*}$ & $17(42.5 \%)$ \\
\hline 2. Discoid rash & $75(28.8 \%)$ & $63(28.6 \%)$ & $12(30.0 \%)$ \\
\hline 3. Photosensitivity & $172(66.2 \%)$ & $152(69.1 \%)^{*}$ & $20(50.0 \%)$ \\
\hline 4. Oral ulcers & $48(18.7 \%)$ & $41(18.9 \%)$ & $7(17.5 \%)$ \\
\hline 5. Arthritis & $195(75.3 \%)$ & $171(78.1 \%)^{*}$ & $24(60.0 \%)$ \\
\hline 6. Serositis & $107(41.3 \%)$ & $86(39.3 \%)$ & $21(52.5 \%)$ \\
\hline 7. Renal disorder & $85(32.8 \%)$ & $64(29.2 \%)$ & $21(52.5 \%)^{* *}$ \\
\hline 8. Neurological disorder & $36(14.0 \%)$ & $32(14.7 \%)$ & $4(10.0 \%)$ \\
\hline 9. Haematological disorder & $138(53.1 \%)$ & $117(53.2 \%)$ & $21(52.5 \%)$ \\
\hline 10. Immunological disorder & $188(72.3 \%)$ & $155(70.5 \%)$ & $33(82.5 \%)$ \\
\hline 11. Antinuclear antibody & $254(97.7 \%)$ & $216(98 \%)$ & $38(95 \%)$ \\
\hline Number of ACR criteria (mean (SD)) & $5.5(1.4)$ & $5.6(1.3)$ & $5.4(1.5)$ \\
\hline SLICCミ (mean (SD)) & $2.4(2.5)$ & $2.3(2.4)$ & $2.9(2.9)$ \\
\hline Cognitive impairment & $33(12.8 \%)$ & $28(12.8 \%)$ & $5(12.5 \%)$ \\
\hline Angina or coronary artery bypass & $27(10.4 \%)$ & $20(9.1 \%)$ & $7(17.5 \%)$ \\
\hline Peripheral vascular involvement & $37(14.4 \%)$ & $27(12.3 \%)$ & $10(25.0 \%)^{*}$ \\
\hline Diabetes & $13(5.0 \%)$ & $8(3.6 \%)$ & $5(12.5 \%)^{*}$ \\
\hline SLEDAI $\uparrow$ (mean (SD)) & $3.4(4.4)$ & $3.2(4.1)$ & $4.5(5.5)$ \\
\hline Haematuria & $26(10.0 \%)$ & $19(8.7 \%)$ & $7(17.5 \%)$ \\
\hline Proteinuria & $25(9.7 \%)$ & $17(7.8 \%)$ & $8(20.0 \%)^{*}$ \\
\hline CNS involvement & $9(3.5 \%)$ & $5(2)$ & $4(10)^{*}+$ \\
\hline \multicolumn{4}{|c|}{$\begin{array}{l}\text { Values are } n(\%) \text { unless stated otherwise. Of the SLICC and SLEDAI groups only variables significantly different } \\
\text { between sexes or by presumptions from published reports are shown. } \\
{ }^{*} \mathrm{p}<0.05,{ }^{* *} \mathrm{p}<0.01,+ \text { Fisher's exact test. } \\
\text { †American College of Rheumatology criteria. }{ }^{31,32} \\
\S S L I C C, \text { Systemic Lupus International Collaborating Clinics. }{ }^{34} \\
\text { ๆSLEDAI, SLE disease activity index. }\end{array}$} \\
\hline
\end{tabular}

\section{METHODS \\ Subjects}

All patients with possible SLE were collected from departments of rheumatology $(n=4)$, internal medicine $(n=12)$, dermatology $(\mathrm{n}=3)$, all primary health care centres $(n=140)$, and a private practitioner, from the four most northern counties of Sweden. The patients had to fulfil at least four of the 1982 American College of Rheumatology (ACR) classification criteria ${ }^{31}$ and the updated criteria ${ }^{32}$ for SLE to be included in the study. Five rheumatologists assessed the patients to determine their disease activity with the SLE activity index (SLEDAI) $)^{33}$ and the organ damage with the Systemic Lupus International Collaborating Clinics/ACR (SLICC) index..$^{34}$ In all, 279 patients fulfilling the ACR criteria for SLE, of whom 260 (220 women (84.6\%) and 40 men $(15.4 \%))$ were willing to participate in the study. Demographic and significant clinical data on the patients are presented in table 1.

Table 2 Primers and probes for the $5^{\prime}$ nuclease assay

\begin{tabular}{ll}
\hline Pvull & \\
fw primer & 5'-CTGTGTTGTCCATCAGTTCATCTG-3' \\
rev primer & 5'-ACTCAGGGTCTCTGGGAAACAG-3' \\
T allele probe & 5'-VIC-CCAGCTGTITATG-MGB*-Qt-3' \\
C allele probe & 5'-6FAM-CCAGCCGTTTAT-MGB*-Qt-3' \\
& \\
Xbal & \\
fw primer & 5'-GTCCATCAGTCATCTGAGTCCAA-3' \\
rev primer & 5'-AGAACCATAGAGACCAATGCTCATC-3' \\
A allele probe & 5'-VIC-AGTGTGGTCTAGAGTTG-MGB*-Q+3' \\
G allele probe & 5'-6FAM-TGTGGTCTGGAGTTG-MGB*-Qt-3' \\
\hline & \\
*Minor groove binder. \\
TQuencher.
\end{tabular}

The controls were geographically matched and randomly collected from the northern Sweden part of the World Health Organisation (WHO) study for monitoring of trends and determinants in cardiovascular disease (MONICA). The control cohort was population based, stratified for age and sex, and no individual was excluded. The controls were only used to compare genotype and allele frequencies. The control cohort comprised 670 individuals, 490 women $(73.1 \%)$ and 180 men $(26.9 \%)$. The mean (SD) age of the controls was 59.4 (12.4) years for women and 64.1 (10.2) years for men. The project was approved by the regional ethics committee of the University Hospital in Umeå, Sweden.

\section{Methods}

Genomic DNA from the patients was extracted from whole blood (EDTA treated) using the standard phenol/chloroform extraction method $(\mathrm{n}=161)^{35}$ and the salting out method $(\mathrm{n}=99) .{ }^{36}$ DNA from the controls was extracted using the FlexiGene DNA kit supplied by Qiagen (Valencia, California, USA). The PvuII and XbaI polymorphisms were determined using the $5^{\prime}$ nuclease assay. ${ }^{37}$ Primers and probes were designed using Assays-by-Design (Applied Biosystems, Foster City, California, USA) (table 2 ). The probes were labelled at their $5^{\prime}$ ends with FAM $^{\mathrm{TM}}$ (the first allele) and $\mathrm{VIC}^{\mathrm{TM}}$ (the second allele), and the $3^{\prime}$ ends contained quenchers. Primers and probes were mixed with TaqMan ${ }^{\circledR}$ Universal PCR Master Mix, No AmpErase ${ }^{\circledR}$ UNG, and added to 96-well microtitre plates, each well containing $10 \mathrm{ng}$ of air dried DNA. The polymerase chain reactions (PCR) were carried out according to Applied Biosystems instructions, and detection of the different genotypes was done using an ABI PRISM $^{\circledR}$ 7900HT sequence detector system (Applied Biosystems). Data were processed using SDS 2.1 software (Applied Biosystems). 
Table 3 Genotype frequencies of the patients and controls

\begin{tabular}{|c|c|c|c|c|c|c|c|}
\hline & & \multicolumn{3}{|l|}{ Patients (\%) } & \multicolumn{3}{|l|}{ Controls (\%) } \\
\hline & & Women $(n=220)$ & Men $(n=40)$ & Total $(n=260)$ & Women $(n=490)$ & Men $(n=180)$ & Total $(n=670)$ \\
\hline \multirow[t]{3}{*}{ Pvull } & $\mathrm{CC}$ & 16.8 & 20.0 & 17.3 & 18.0 & 23.3 & 19.4 \\
\hline & $\mathrm{CT}$ & 52.7 & 40.0 & 50.8 & 49.4 & 50.0 & 49.6 \\
\hline & $\pi$ & 30.5 & 40.0 & 31.9 & 32.7 & 26.7 & 31.0 \\
\hline \multirow[t]{3}{*}{ Xbal } & GG & 7.7 & 10.0 & 8.1 & 7.8 & 11.1 & 8.6 \\
\hline & GA & 37.7 & 27.5 & 36.2 & 40.8 & 44.4 & 41.9 \\
\hline & AA & 54.5 & 62.5 & 55.8 & 51.4 & 44.4 & 49.5 \\
\hline
\end{tabular}

The different genotypes were verified by comparison with controls of known genotype.

\section{Statistical methods}

Continuous data were analysed using Student's $t$ test for independent samples. Categorical data were analysed using the $\chi^{2}$ test or Fisher's exact test as appropriate. Calculations of the odds ratios (ORs) were done using binary logistic regression, adjusted for sex, with male subjects as reference, and for age at disease onset. The relation between a variable and an allele, with appropriate adjustments, was analysed using the univariate analysis of variance.

The statistical program used for the calculations was SPSS (SPSS for Windows, version 11.5; Chicago, Illinois, USA). All $\mathrm{p}$ values refer to two sided tests, with values less than 0.05 considered significant.

\section{Strategy of analysis}

The strategy for choosing variables for binary logistic regression analyses was based on conclusions drawn from previous reports on these single nucleotide polymorphisms (SNPS) in SLE and other diseases, and by including variables found to differ significantly between the sexes. The difference between the sexes could be oestrogen dependent.

\section{RESULTS}

The distribution of genotypes in both the patients and the controls was in agreement with the Hardy-Weinberg equilibrium, and the genotypes and allele frequencies of the patients did not differ significantly from the controls (table 3). PvuII and XbaI are tightly linked, ${ }^{27}$ so a classification of the nine possible combined genotypes was made (table 4). There was no significant difference in the combined genotypes between patients and controls.

By stratifying for the ACR criteria and genotypes of the PvuII and XbaI polymorphisms it was found that malar rash was associated with the PvuII genotypes $(p=0.022$, $\left.\mathrm{p}_{\mathrm{c}}=0.242\right)$ and that photosensitivity and serositis were associated with the XbaI genotypes $\left(\mathrm{p}=0.013, \mathrm{p}_{\mathrm{c}}=0.143\right.$ and $\mathrm{p}=0.009, \mathrm{p}_{\mathrm{c}}=0.099$, respectively) (table 5 ). The binary logistic regression showed that malar rash was associated with carriage of the PvuII C allele $(p=0.001, \quad O R=2.53$ (95\% CI, 1.43 to 4.47$)$ ) and the XbaI G allele ( $p=0.027$, $\mathrm{OR}=1.82(1.31$ to 4.57$)$ ) (table 6). By adjusting for sex and age at disease onset there was a slight increase in odds ratios. Photosensitivity was also associated with the XbaI G allele ( $p=0.007, O R=2.12(95 \%$ CI, 1.22 to 3.66)) with an approximately similar odds ratio when adjusted for sex and age at onset (table 6). Serositis was associated with the XbaI AA genotype $(\mathrm{p}=0.013, \mathrm{OR}=1.92$ (95\% CI, 1.15 to 3.22$)$ ) and the XbaI G allele was protective for serositis $(p=0.011, O R=0.51(0.31$ to 0.86$)$ ) (table 6). Adjustments for sex and age at onset did not affect the odds ratios.

Using the SLICC damage index, the relation of genotype with cognitive impairment was analysed. The PvuII TT genotype $(p=0.018, O R=2.47(95 \% \mathrm{CI}, 1.17$ to 5.25$))$, as well as the XbaI AA genotype $(\mathrm{p}=0.018, \mathrm{OR}=2.75$ ( 1.19 to $6.38)$ ) was found to be significantly associated with cognitive impairment, unrelated to the adjustments (table 7).

As there are previous reports on PvuII and XbaI associations with coronary artery disease ${ }^{38} 39$ and cardiovascular disease, ${ }^{21} 4041$ the predicted values for cardiovascular manifestations were analysed. There was an association for individuals carrying the XbaI AA genotype $(\mathrm{p}=0.042$, $\mathrm{OR}=2.58(95 \%$ CI, 1.03 to 6.43$))$ with the SLICC damage index for angina/coronary artery bypass (table 7). Adjustments did not affect the odds ratios.

Comparison was made of the variables characterising the severity of the disease (number of ACR criteria, SLICC index, and SLEDAI) and age at disease onset in relation to the different genotypes. Carriers of the unusual PvuII C allele showed a later onset of SLE $(p=0.02)$ and carriers of the unusual XbaI $G$ allele indicated a lower value for SLICC index $(p=0.028)$ (table 8$)$. This relation remained after adjustment for disease duration.

There were no significant associations with the ACR criteria for arthritis and renal disorder, or with the SLICC damage index for peripheral vascular involvement and diabetes despite their differences in sexual prevalence.

Table 4 Combined genotype frequencies of the patients and controls

\begin{tabular}{|c|c|c|c|c|c|c|}
\hline \multirow{2}{*}{ Genotypes } & \multicolumn{3}{|l|}{ Patients (\%) } & \multicolumn{3}{|l|}{ Controls (\%) } \\
\hline & Women $(n=220)$ & Men $(n=40)$ & Total $(n=260)$ & Women $(n=490)$ & Men $(n=180)$ & Total $(n=670)$ \\
\hline CCGG & 7.7 & 10.0 & 8.1 & 7.6 & 11.1 & 8.5 \\
\hline CCGA & 6.8 & 5.0 & 6.5 & 8.0 & 11.1 & 8.8 \\
\hline CCAA & 2.3 & 5.0 & 2.7 & 2.4 & 1.1 & 2.1 \\
\hline CTGG & 0.0 & 0.0 & 0.0 & 0.2 & 0.0 & 0.1 \\
\hline CTGA & 30.9 & 22.5 & 29.6 & 32.7 & 33.3 & 32.8 \\
\hline CTAA & 21.8 & 17.5 & 31.2 & 16.5 & 16.7 & 16.6 \\
\hline TTGG & 0.0 & 0.0 & 0.0 & 0.0 & 0.0 & 0.0 \\
\hline TTGA & 0.0 & 0.0 & 0.0 & 0.2 & 0.0 & 0.1 \\
\hline TTAA & 30.5 & 40.0 & 31.9 & 32.4 & 26.7 & 30.9 \\
\hline
\end{tabular}


Table 5 Comparison between the genotypes of the two polymorphisms and the ACR criteria

\begin{tabular}{|c|c|c|c|c|c|c|c|c|}
\hline \multirow[b]{2}{*}{ ACR criteria (1-11) } & \multicolumn{3}{|l|}{ Pvull } & \multirow[b]{2}{*}{ p Value* } & \multicolumn{3}{|l|}{ Xbal } & \multirow[b]{2}{*}{ p Value* } \\
\hline & $C C(n=45)$ & TC $(n=132)$ & $\Pi(n=83)$ & & GG $(n=21)$ & AG $(n=94)$ & $A A(n=145)$ & \\
\hline 1. Malar rash & $27(60.0)$ & $84(63.6)$ & $38(45.8)$ & 0.022 & $14(66.7)$ & $60(63.8)$ & $75(51.7)$ & 0.12 \\
\hline 2. Discoid rash & $15(33.3)$ & $42(31.8)$ & $18(21.7)$ & 0.21 & $8(38.1)$ & $25(26.6)$ & $42(29.0)$ & 0.57 \\
\hline 3. Photosensitivity & $32(71.1)$ & $89(67.4)$ & $51(61.4)$ & 0.49 & $17(81.0)$ & $70(74.5)$ & $85(58.6)$ & 0.013 \\
\hline 4. Oral ulcer & $10(22.2)$ & $24(18.2)$ & $14(16.9)$ & 0.75 & $4(19.0)$ & $15(16.0)$ & $29(20.0)$ & 0.73 \\
\hline 5. Arthritis & 33 (73.3) & 97 (73.5) & 65 (78.3) & 0.70 & $12(57.1)$ & 74 (78.7) & 109 (75.2) & 0.12 \\
\hline 6. Serositis & $19(42.2)$ & $50(37.9)$ & $36(45.8)$ & 0.51 & $10(47.6)$ & $27(28.7)$ & $70(48.3)$ & 0.009 \\
\hline 7. Renal disease & $16(35.6)$ & $41(31.1)$ & $28(33.7)$ & 0.83 & $8(38.1)$ & $29(30.9)$ & $48(33.1)$ & 0.81 \\
\hline 8. Neurological disease & $4(8.9)$ & $19(14.4)$ & $13(15.7)$ & 0.55 & $1(4.8)$ & $12(12.8)$ & $23(15.9)$ & 0.36 \\
\hline 9. Haematological disease & $23(51.1)$ & 72 (51.5) & $47(56.6)$ & 0.73 & $11(52.4)$ & $52(55.3)$ & $75(51.7)$ & 0.86 \\
\hline 10. Immunological disease & $34(75.6)$ & $90(68.2)$ & $64(77.1)$ & 0.31 & $12(57.1)$ & $66(70.2)$ & $106(73.1)$ & 0.32 \\
\hline 11. ANA & $43(95.6)$ & $131(99.2)$ & $80(96.4)$ & 0.23 & $20(95.2)$ & $93(98.9)$ & 141 (97.2) & 0.51 \\
\hline
\end{tabular}

No association analysis was undertaken with osteoporosis as it had been measured inconsistently in the patients.

\section{DISCUSSION}

In this cross sectional study of patients diagnosed with SLE, the data collected were related to the ACR criteria, the SLEDAI score, and the SLICC damage index. Data analyses were based on findings of significant differences between the sexes and on significant findings reported by others. The patients originate from a relatively homogeneous population from the four northernmost counties of Sweden, all having the same ethnic background. The controls were derived from the same population. This population is considered to be well suited to genetic association studies as it derives from a founder population that has been relatively isolated throughout history.

When analysing the variables describing the severity of the disease, it was found that individuals carrying the unusual PvuII C allele had a later onset of SLE and those carrying the unusual XbaI G allele had a lower SLICC damage index value, unrelated to disease duration. This could indicate that carriage of these alleles results in a milder form of the disease. However, there are no differences between carriers of the unusual alleles or usual alleles when considering the number of ACR criteria or the sum of disease activity measured by the SLEDAI score. Our finding concerning age at disease onset is consistent with that reported by Lee et al,

Table 6 Binary logistic regression analysis of patients with ACR criteria 1, 3, and 6

\begin{tabular}{|c|c|c|c|c|c|c|}
\hline \multirow[b]{2}{*}{ Variable } & \multicolumn{3}{|c|}{ Univariate analysis } & \multicolumn{3}{|c|}{ Multivariate analysis } \\
\hline & B & p Value & OR $(95 \% \mathrm{Cl})$ & B & $\mathrm{p}$ Value & OR $(95 \% \mathrm{Cl})$ \\
\hline \multicolumn{7}{|l|}{ Malar rash } \\
\hline Pvull carrier of C & 0.704 & 0.009 & 2.022 (1.191 to 3.433 ) & 0.927 & 0.001 & 2.526 (1.427 to 4.473 ) \\
\hline Sex (males reference) & & & & -0.564 & 0.127 & $0.569(0.276$ to 1.175$)$ \\
\hline Age at onset & & & & -0.037 & 0.000 & 0.964 (0.947 to 0.981$)$ \\
\hline Xbal carrier of $G$ & 0.546 & 0.034 & 1.727 (1.043 to 2.858$)$ & 0.598 & 0.027 & 1.818. (1.070 to 3.088$)$ \\
\hline Sex (males reference) & & & & -0.605 & 0.099 & $0.546(0.266$ to 1.121$)$ \\
\hline Age at onset & & & & -0.033 & 0.000 & $0.967(0.951$ to 0.984$)$ \\
\hline \multicolumn{7}{|l|}{ Photosensitivity } \\
\hline Xbal carrier of $G$ & 0.785 & 0.004 & 2.193 (1.279 to 3.760$)$ & 0.750 & 0.007 & 2.117 (1.224 to 3.661$)$ \\
\hline Sex (males ref.) & & & & -0.754 & 0.034 & 0.470 (0.234 to 0.945$)$ \\
\hline Age at onset & & & & -0.006 & 0.471 & 0.994 (0.977 to 1.011$)$ \\
\hline \multicolumn{7}{|l|}{ Serositis } \\
\hline Xbal AA & 0.664 & 0.011 & 1.942 (1.167 to 3.2234$)$ & 0.653 & 0.013 & 1.922 (1.146 to 3.223 ) \\
\hline Sex (males reference) & & & & 0.539 & 0.127 & 1.714 (0.859 to 3.419$)$ \\
\hline Age at onset & & & & -0.004 & 0.656 & 0.996 (0.980 to 1.013$)$ \\
\hline Xbal carrier of $G$ & -0.677 & 0.009 & $0.508(0.306$ to 0.846$)$ & -0.667 & 0.011 & $0.513(0.306$ to 0.860$)$ \\
\hline Sex (males reference) & & & & 0.543 & 0.124 & 1.721 (0.862 to 3.435$)$ \\
\hline Age at onset & & & & -0.003 & 0.684 & $0.997(0.981$ to 1.013$)$ \\
\hline
\end{tabular}


Table 7 Binary logistic regression analysis of patients with systemic lupus erythematosus assessed by SLICC/ACR damage index

\begin{tabular}{|c|c|c|c|c|c|c|}
\hline \multirow[b]{2}{*}{ Variables } & \multicolumn{3}{|c|}{ Univariate analysis } & \multicolumn{3}{|c|}{ Multivariate analysis } \\
\hline & B & $\mathrm{p}$ Value & OR $(95 \% \mathrm{Cl})$ & B & $p$ Value & OR $(95 \% \mathrm{Cl})$ \\
\hline \multicolumn{7}{|l|}{ Cognitive impairment } \\
\hline Pvull TT & 0.940 & 0.013 & $2.560(1.221$ to 5.368$)$ & 0.906 & 0.018 & 2.474 (1.166 to 5.248$)$ \\
\hline Sex (males reference) & & & & -0.114 & 0.830 & 0.893 (0.316 to 2.519 ) \\
\hline Age at onset & & & & -0.006 & 0.632 & 0.994 (0.970 to 1.019$)$ \\
\hline Xbal AA & 1.024 & 0.017 & 2.784 (1.204 to 6.435$)$ & 1.012 & 0.018 & 2.752 (1.187 to 6.383$)$ \\
\hline Sex (males reference) & & & & -0.083 & 0.875 & 0.920 (0.327 to 2.589$)$ \\
\hline Age at onset & & & & -0.009 & 0.485 & 0.992 (0.968 to 1.016$)$ \\
\hline \multicolumn{7}{|l|}{$\begin{array}{l}\text { Angina or coronary artery } \\
\text { bypass }\end{array}$} \\
\hline Xbal AA & 0.904 & 0.049 & 2.469 (1.005 to 6.062$)$ & 0.948 & 0.042 & 2.580 (1.034 to 6.434$)$ \\
\hline Sex (males reference) & & & & 0.548 & 0.270 & 1.730 (0.653 to 4.579$)$ \\
\hline Age at onset & & & & 0.030 & 0.024 & 1.030 (1.004 to 1.057$)$ \\
\hline
\end{tabular}

who found that SLE patients homozygous for the PvuII $C$ allele were older at disease onset. ${ }^{30}$

Women with SLE more often had skin and joint manifestations than men. The unusual alleles PvuII $\mathrm{C}$ and XbaI G were shown to be associated with skin involvement; however, there were no associations of these alleles with arthritis. The $\mathrm{C}$ allele of PvuII was related to malar rash with a higher odds ratio than the $\mathrm{G}$ allele of XbaI and conversely the $\mathrm{G}$ allele of XbaI was in return associated with photosensitivity. As the PvuII $\mathrm{C}$ allele and the XbaI G allele are tightly linked, it is impossible to tell which is more highly related to skin involvement. Skin manifestations, such as malar rash and photosensitivity, are generally regarded as signs of a less severe disease in SLE patients. Skin rashes have in some cases been related to the menstrual periods, suggesting a hormonal influence. ${ }^{42}$

The serositis variable from the ACR criteria is associated with the $\mathrm{XbaI} A \mathrm{~A}$ genotype while the $\mathrm{XbaI} G$ allele is protective for serositis. From these data, it is not possible to conclude which of the genotypes is of importance, as the significance levels were equal; and in view of the numbers of tests carried out, either one or both of the significance values could be the result of a type II error.

There was a significant difference in central nervous system involvement (from the SLEDAI score) between women and men, whereby men had a higher frequency of CNS involvement. A decline in oestrogen is related to bone loss and possibly to loss of cognitive function. It has been suggested that bone loss and cognitive impairment are concurrent conditions, which could reflect their association with oestrogens. ${ }^{43}{ }^{44}$ Oestrogen receptor polymorphisms have been reported to be involved in cognitive impairment which is a neuropsychiatric criterion of the SLICC damage index. There are also reports indicating associations between the OR $\alpha$ polymorphisms and osteoporosis. ${ }^{25}$ We did not undertake any analyses with osteoporosis indices owing to inconsistency in measurements and data collection. Yaffe et al, in a study of healthy women aged 65 years or older, found that those elderly women who carried the PvuII $\mathrm{T}$ allele had a higher risk of developing cognitive impairment. ${ }^{22}$ An association with cognitive function is biologically relevant as oestrogen receptors are located throughout the brain and especially in regions involved with learning and memory. ${ }^{45}$ It has also been shown that oestrogen replacement therapy may benefit cognitive function in postmenopausal women. ${ }^{46}$ Our results were consistent with those of Yaffe et al regarding the $\mathrm{T}$ allele ${ }^{22}$ when the PvuII TT genotype was found to be significantly associated with cognitive impairment. Cognitive impairment was also found to be associated with the XbaI AA genotype. This is logical because of the strong linkage between the two polymorphisms. The XbaI AA genotype had a slightly higher odds ratio, which may indicate that this polymorphism is the one associated with cognitive impairment while the PvuII TT only shows significance because of the linkage. The data were not further stratified for age and therefore the specific association with older women as reported by Yaffe et $a^{22}$ could not be identified.

Women with SLE have been reported to have significantly increased rates of myocardial infarction compared with those without SLE. ${ }^{47}{ }^{48}$ The PvuII and the XbaI polymorphisms of the oestrogen receptor gene have been studied extensively in several cardiovascular related diseases. Oestrogen receptor $\alpha$ has been found in smooth muscle cells, endothelial cells, and myocardial cells of the coronary artery wall. ${ }^{21}$ Other reports indicate that the XbaI GG genotype and the PvuII TT genotype are associated with coronary artery disease, ${ }^{38}{ }^{39}$ the PvuII CC genotype being associated with cardiovascular disease $^{40}$ and with coronary disease ${ }^{41}$ and that the PvuII $\mathrm{T}$ allele and the XbaI A allele are associated with myocardial infarction. ${ }^{21}$ The XbaI AA genotype was associated with angina/coronary artery bypass of the SLICC index in our SLE patients. This can be related to the findings of Schuit et al, who reported associations of the TA haplotype (combination of PvuII $\mathrm{T}$ and XbaI A) with myocardial infarction and

Table 8 Continuous variables describing the disease and the differences between patients carrying the unusual alleles (Pvull C and Xbal G) versus not carrying these alleles

\begin{tabular}{llll}
\hline Type & Age of onset & Number of ACR criteria & SLICC index \\
\hline Pvull carrier of C allele/carrier of non-C & $40.6(1.2)^{*} / 35.7(1.7)$ & $5.6(0.1) / 5.5(0.1)$ & $2.3(0.2) / 2.5(0.3)$ \\
Xbal carrier of G allele/carrier of non-G & $40.0(1.4) / 38.2(1.3)$ & $5.6(0.1) / 5.5(0.1)$ & $2.0(0.2)^{*} / 2.7(0.2)$ \\
\hline Values are mean (SEM). & & & $3.5(0.3) / 3.4(0.6)$ \\
* $<<0.05$, all analysed by Student's $t$ test. & & \\
SLEDAI, SLE disease activity index; SLICC, Systemic Lupus International Collaborating Clinics.
\end{tabular}


ischaemic heart disease in women. ${ }^{21}$ There was no association with the other genotypes, which might indicate that the oestrogen receptor involvement in angina/coronary artery bypass is similar to that in myocardial infarction and ischaemic heart disease.

How these polymorphisms alter the function or expression of the receptor is unknown. They are both intronic polymorphisms and it has been reported that the PvuII $\mathrm{C}$ allele produces a binding site for the myb family of transcription factors. In presence of B-myb there was a four times greater upregulation of a downstream reporter construct compared with that seen with the T allele. ${ }^{41}{ }^{49}$ Thus the PvuII C allele could lead to an upregulation of the OR $\alpha$ transcription or an alteration of the OR $\alpha$ transcript. The role of the XbaI polymorphism is still unclear except for its strong linkage to the PvuII polymorphism.

The limitations of this study comprise the size of the patient group, which is relatively small owing to the low incidence of SLE, though all patients fulfilling the criteria for SLE from northern Sweden were included. Also, because of the number of statistical tests carried out, some of the results with lower significance values have to be interpreted with care and should be seen as indications rather than truly significant findings until they are confirmed by further studies.

In conclusion, the unusual alleles PvuII $\mathrm{C}$ and XbaI G were found in patients with a greater age at disease onset and with a lower SLICC index score, and were also associated with skin involvement. The $\mathrm{C}$ allele is highly associated with malar rash and the $G$ allele with photosensitivity. These findings indicate that the unusual alleles of these OR $\alpha$ polymorphisms (PvuII C and XbaI G) are associated with less severe disease manifestations such as skin involvement. The more common alleles PvuII T and XbaI A were found to be associated with the cognitive impairment and angina/coronary artery bypass variables from the SLICC damage index, and also with serositis from the ACR criteria.

\section{ACKNOWLEDGEMENTS}

This work was supported by grants from "Visare Norr", Samverkansnämden för Norra Regionen. We thank Professor Göran Hallmans, the Blood bank of Northern Sweden, and Birgitta Stegmayr PhD, Department of Medicine, for providing control samples from the WHO-MONICA cohort. We gratefully acknowledge Solveig Linghult and Maria Lindberg for technical assistance. This study was made possible by a collaborative project on SLE from the four most northern counties of Sweden. The colleagues concerned were: Lisbeth Söderlund MD, Luleå; Johan Back MD, Sundsvall; Ann-Cathrin Åkesson MD, Sollefteå; Catharina Eriksson MD, Umeå; and Berndt Stegmayr MD, PhD, Internal Medicine, Umeå, Sweden.

\section{Authors' affiliations}

M Johansson, L Ärlestig, S Rantapää-Dahlqvist, Department of

Rheumatology, University Hospital, Umeå, Sweden

B Möller, Sunderbyns Hospital, Luleå, Sweden

T Smedby, County Hospital, Östersund, Sweden

\section{REFERENCES}

1 Dubois EL. The clinical picture of systemic lupus erythematosus. In: Dubois EL, ed. Lupus erythematosus. Los Angeles: University of South California Press, 1974:232-42.

2 Beeson PB. Age and sex associations of 40 autoimmune diseases. Am J Med 1994;96:457-62

3 McMurray RW, May W. Sex hormones and systemic lupus erythematosus: review and meta-analysis. Arthritis Rheum 2003;48:2100-10.

4 Masi AT, Kaslow RA. Sex effects in systemic lupus erythematosus: a clue to pathogenesis. Arthritis Rheum 1978;21:480-4.

5 McMurray RW. Estrogen, prolactin, and autoimmunity: actions and interactions. Int Immunopharmacol 2001;1:995-1008.

6 Tanriverdi F, Silveira LF, MacColl GS, Bouloux PMG. The hypothalamicpituitary-gonadal axis: immune function and autoimmunity. $J$ Endocrinol 2003; 176:293-304

7 Nilsson N, Carlsten H. Estrogen induces suppression of natural killer cell cytotoxicity and augmentation of polyclonal B cell activation. Cell Immunol 1994; 158:131-9.
8 Kanda N, Tsuchida T, Tamaki K. Estrogen enhancement of anti-doublestranded DNA antibody and immunoglobulin $G$ production in peripheral blood mononuclear cells from patients with systemic lupus erythematosus. Arthritis Rheum 1999:42:328-37.

9 Ansar AS, Penhale WJ, Talal N. Sex hormones, immune response and autoimmune disease: mechanism of sex hormone action. Am J Pathol 1985;121:531-51.

10 Lahita RG. Sex and age in systemic lupus erythematosus. In: Lahita RG, ed Systemic lupus erythematosus. New York: John Wiley, 1986:523-39.

11 Beaumont V, Gioud-Paquet M, Kahn MF, Beaumont JL. Antiestrogen antibodies, oral contraception and systemic lupus erythematosus. Clin Physiol Biochem 1989:7:263-89.

12 Jungers $\mathbf{P}$, Dougados $M$, Pelissier $C$, Kuttenn F, Tron F, Lesavre $P$, et al. Influence of oral contraceptive therapy on the activity of systemic lupus erythematosus. Arthritis Rheum 1982;25:618-23.

13 Garovich M, Agudelo C, Pisko E. Oral contraceptives and systemic lupus erythematosus. Arthritis Rheum 1980;23:1396-8.

14 Mund A, Simson J, Rothfield N. Effect of pregnancy on course of systemic lupus erythematosus. JAMA 1963;183:109-12.

15 Hayslett JP, Reece EA. Systemic lupus erythematosus in pregnancy. Clin Perinatol 1985; 12:539-50.

16 Jungers $\mathbf{P}$, Dougados $M$, Pelissier $C$, Kuttenn $F$, Tron $F$, Lesavre $P$, et al. Lupus nephropathy and pregnancy: report of 104 cases in 36 patients. Arch Intern Med 1982;142:771-6.

17 Ruiz-Irastorza G, Lima F, Alves J, Khamashata MA, Simpson J, Hughes GR, et al. Increased rate of lupus flare during pregnancy and the puerperium: a prospective study of 78 pregnancies. Br J Rheumatol 1996;35:133-8.

18 Lockshin MD. Pregnancy does not cause systemic lupus erythematosus to worsen. Arthritis Rheum 1989;32:665-70.

19 Steinberg AD, Steinberg BJ. Lupus disease activity associated with menstrual cycle. J Rheumatol 1985; 12:816-17.

20 Enmark E, Gustafsson JÂ. Oestrogen receptors - an overview. J Intern Med 1999;246:133-8.

21 Schuit SC, Oei HH, Witteman JC, Geurts van Kessel CH, van Meurs JB, Nijhuis RL, et al. Estrogen receptor alpha gene polymorphisms and risk of myocardial infarction. JAMA 2004;291:2969-77.

22 Yaffe K, Lui LY, Grady D, Stone K, Morin P. Estrogen receptor 1 polymorphisms and risk of cognitive impairment in older women. Biol Psychiatry 2002;51:677-82.

23 Andersen TI, Heimdal KR, Skrede M, Tveit K, Berg K, Borresen AL. Oestrogen receptor (ESR) polymorphisms and breast cancer susceptibility. Hum Genet 1994:94:665-70.

24 Mattila KM, Axelman K, Rinne JO, Blomberg M, Lehtimaki T, Laippala P. Interaction between estrogen receptor 1 and the epsilon4 allele of apolipoprotein $E$ increases risk of familial Alzheimer's disease in women. Neurosci Lett 2000;282:45-8.

25 Khosla S, Riggs BL, Atkinson EJ, Oberg AL, Mavilia C, Del Monte F. Relationship of estrogen receptor genotypes to bone mineral density and to rates of bone loss in men. J Clin Endocrinol Metab 2004;89:1808-16.

26 Ushiyama T, Mori K, Inoue K, Huang J, Nishioka J, Hukuda S. Association of estrogen receptor gene polymorphisms with age of onset of rheumatoid arthritis. Ann Rheum Dis 1999;58:7-10.

27 Liu ZH, Cheng ZH, Gong RJ, Liu H, Liu D, Li LS. Sex differences in estrogen receptor gene polymorphism and its association with lupus nephritis in Chinese. Nephron 2002;90:174-8.

28 Gonzalez-Gomez F, Vergara F, Fernandez A, Pedrosa C, Ramirez JP, Casilla JA, et al. Detection of pvull polymorphism within intron 1 of ESR1 gene by real-time PCR. Clin Chem Lab Med 2003;41:392-3.

29 Herrington DM, Howard TD. ER- $\alpha$ variants and the cardiovascular effects of hormone replacement therapy. Pharmacogenomics 2003:4:269-77.

30 Lee YJ, Shin KS, Kang SW, Lee CK, Yoo B, Cha HS, et al. Association of the oestrogen receptor $\alpha$ gene polymorphisms with disease onset in systemic lupus erythematosus. Ann Rheum Dis 2004;63:1244-9.

31 Tan EM, Cohen AS, Fries JF, Masi AT, McShane DJ, Rothfield NF, et al. The 1982 revised criteria for the classification of systemic lupus erythematosus. Arthritis Rheum 1982;25:1271-7.

32 Hochberg MC. Updating the American College of Rheumatology revised criteria for classification of systemic lupus erythematosus. Arthritis Rheum 1997:40:1725.

33 Bombardier C, Gladman DD, Urowitz MB, Caron D, Chang CH. Derivation of the SLEDAI. A disease activity index for lupus patients. The Committee on Prognosis Studies in SLE. Arthritis Rheum 1992;35:630-40.

34 Gladman D, Ginzler E, Goldsmith C, Fortin P, Liang M, Urowitz M, et al. The development and initial validation of the Systemic Lupus International Collaborating Clinics/American College of Rheumatology damage index for systemic lupus erythematosus. Arthritis Rheum 1996;39:363-9.

35 Ausubel FM. Current protocols in molecular biology. In: Brent R, Kingston RE, Moore DD, Seidman JG, Smith JA, Struhl K, eds. Wiley Interscience. New York, John Wiley, 1995

36 Miller SA, Dykes DD, Polesky HF. A simple salting out procedure for extracting DNA from human nucleated cells. Nucleic Acids Res 1988;16:1215.

37 Livak KJ, Marmaro J, Todd JA. Towards fully automated genome-wide polymorphism screening. Nat Genet 1995;9:341-2.

38 Lu H, Higashikata T, Inazu A, Nohara A, Yu W, Shimizu M, et al. Association of estrogen receptor- $\alpha$ gene polymorphisms with coronary artery disease in patients with familial hypercholesterolemia. Arterioscler Thromb Vasc Biol 2002;22:821-7.

39 Ferrero V, Ribichini F, Matullo G, Guarrera, Carturan S, Vado A, Vassanelli $C$, et al. Estrogen receptor- $\alpha$ polymorphisms and angiographic outcome after coronary artery stenting. Arterioscler Thromb Vasc Biol 2003;23:2223-8. 
40 Shearman AM, Cupples LA, Demissie S, Peter I, Schmis CH, Karas RH, et al. Association between estrogen receptor $\alpha$ gene variation and cardiovascular disease. JAMA 2003;290:2263-70.

41 Herrington DM, Howard TD, Hawkins GA, Reboussin DM, Xu J, Zheng SL, et al. Estrogen-receptor polymorphisms and effects of estrogen replacement on high-density lipoprotein cholesterol in women with coronary disease. NEngl J Med 2002;346:967-74.

42 Pando JA, Gourley MF, Wilder RL, Crofford U. Hormonal supplementation as treatment for cyclical rashes in patients with systemic lupus erythematosus. J Rheumatol 1995;22:1259-62.

43 Zhang Y, Seshadri S, Ellison RC, Heeren T, Felson DT. Bone mineral density and verbal memory impairment: Third National Health and Nutrition Examination Survey. Am J Epidemiol 2001;154:795-802.

44 Yaffe K, Browner W, Cauley J, Launer L, Harris T. Association between bone mineral density and cognitive decline in older women. J Am Geriatr Soc 1999;47:1176-82.
45 Shughrue PJ, Lane MV, Merchenthaler I. Comparative distribution of estrogen receptor-alpha and -beta mRNA in the rat central nervous system. J Comp Neurol 1997;388:507-25

46 Maki PM, Zonderman AB, Resnick SM. Enhanced verbal memory in nondemented elderly women receiving hormone-replacement therapy. Am J Psychiatry 2001;158:227-333.

47 Manzi S, Meilahn EN, Rairie JE, Conte CG, Medsger TA, JansenMcWilliams $L$, et al. Age-specific incidence rates of myocardial infarction and angina in women with systemic lupus erythematosus: comparison with the Framingham study. Am J Epidemiol 1997;145:408-15.

48 Ward MM. Premature morbidity from cardiovascular and cerebrovascular diseases in women with systemic lupus erythematosus. Arthritis Rheum 1999:42:338-46.

49 Herrington DM, Howard TD, Brosnihan KB, McDonnell DP, Li X, Hawkins GA, et al. Common estrogen receptor polymorphism augments effects of hormone replacement therapy on E-selectin but not C-reactive protein. Circulation 2002; 105: 1879-82.

\section{Get published within days of acceptance with ARD}

We are delighted to announce that the Annals of the Rheumatic Diseases launched a "publish ahead of print" programme in February 2004. Selected papers are fast tracked and published online months before they appear in the print journal.

Papers of major significance to the international rheumatology community are published within days of acceptance. The first published article is the raw accepted manuscript; edited and typeset versions are also published as soon as they are available.

In addition to being available on ARD Online, the publish ahead of print articles are searchable through PubMed/ Medline-establishing primacy for your work. They are linked from the ARD Online home page.

To take advantage of this "publish ahead of print" programme submit your papers to the Annals of the Rheumatic Diseases using our online submission and review system Bench $>$ Press (http://submit-ard.bmijournals. com). For further information contact ARD@bmigroup.com. 